\title{
Global Collaborative Research and Development
}

\author{
J. T. Trevors • N. Stavros • M. H. Saier Jr.
}

Published online: 22 April 2008

(C) Springer Science + Business Media B.V. 2008

Excellent research is immensely challenging and difficult to successfully complete. Nature's complex secrets are revealed slowly, sometimes by accident and sometimes not at all. To unlock these secrets, you need to train researchers, sometimes for as long as a decade. You use advanced equipment, which is often as expensive to purchase as it is to operate and maintain. You also need supervisors for the personnel, such as an advisory committee. Data analysis requires powerful computing capabilities. There are publications costs, travel to study sites and meetings, student stipends and salaries for technical staff and postdoctoral fellows. It adds up to a massive sum, and there is still no guarantee the research effort will yield significant scientific, scholarly or technological benefit.

\footnotetext{
J. T. Trevors $(\square)$

Department of Environmental Biology,

University of Guelph,

Guelph, ON NIG-2W1, Canada

e-mail: jtrevors@uoguelph.ca

N. Stavros $\cdot$ M. H. Saier Jr.

Division of Biological Sciences,

University of California at San Diego,

La Jolla, CA 92093-0116, USA

N. Stavros

e-mail: nstavros@ucsd.edu

M. H. Saier Jr.

e-mail: msaier@ucsd.edu
}

Discovery-oriented research is expensive, but it is crucial for breakthroughs that can help people all over the world. The Nations of the world have developed dozens of beneficial disease treatments and forms of birth control to minimize human and planetary suffering. Consider the situation of developing and poorer countries with limited financial resources. Countries that spend a dollar per person per year on health care are not capable of launching and maintaining scholarly research programs on a significant national or international level. Yet research and development are fundamentally important to all people. Disease and strife do not respect national boundaries, and it is imperative that more countries cooperate to tackle the problems that concern humanity.

Numerous species of microorganisms exist in a balanced symbiosis that is absolutely necessary for their survival. Plants such as legumes have nodules containing nitrogen-fixing bacteria. Animals such as aphids and termites rely on bacteria to produce nitrogenous compounds and to digest cellulose. Symbiosis is important at many levels in diverse biological systems. Entire ecosystems often depend on such mutual relationships. Humans are inextricably linked to and dependent on their symbiotic gut microorganisms, although they seldom realize the benefits they derive.

Most scientifically advanced countries favor introversion, but extending a hand to less affluent nations must be forthcoming in order to avoid massive pandemics. As more strains of pathogenic bacteria 
and viruses adapt to the human host, humanity is more likely to be ravaged by new plagues. They can spread suffering across boarders, regardless of citizenship or nationality. That is why sharing discoveries and applications that benefit humanity is so valuable. The entire world is affected by human population growth, resource depletion, and impending AIDS and influenza pandemics. An increasingly dense community will run out of options. We already face problems with waste and sewage, potable water, transportation, and public health. There is a general lack of birth control education in many parts of the world. Political instability, poverty, and vulnerability to sickness take root in a population swollen too big for its own good.

Since numerous countries lack the resources to implement $\mathrm{R}$ and $\mathrm{D}$ programs, it appears that the only mechanism for poorer countries to establish significant public programs is with the continuing assistance of the more wealthy developed countries. In some underdeveloped countries this has happened, but there has not been a united effort. Education deficiencies make things more difficult as the global population expands and consumes ever more. The problems facing humanity do not stop at national borders. There simply needs to be more international research collaboration in a relationship where the wealthier nations pay the bills and the poorer countries benefit from the training and knowledge already available in other nations. We all must contribution to the health of people around the globe.
But little has been done to take these strides towards international cooperation. There are obstacles, of course, that will work against the establishment of a functional global cooperation. Tendencies towards selfishness and ignorance often interfere. A strong sense of nationalism and national security favor isolationism, while greed and competition fuel a constant struggle for profit. The political sphere is shadowed by tension and mistrust. With such superficial motives, a supposed democracy resembles an egocentric dictatorship. There is limited funding and lack of political leadership when it comes to spreading research and education to poorer nations of the world. Unfortunately, some people do not want to share knowledge and solutions, and some deny that a problem even exists.

Selfishness will benefit few. Knowledge of disease and birth control must be made accessible to everyone. There will always be obstacles of national security, but these can be dealt with accordingly. The primary issue is the health of humanity and our supporting environment, and this issue should command the attention of every person who inhabits this Earth. If there is to be an effort for a strong and sustainable future, then the movement must be united. Developed countries must take action to set a positive example, and collaborate internationally to encourage developing nations to take a path that will condemn a future to strife on a hostile planet. United action in an overpopulated world may be the only solution to ensure the health of the biosphere for coming generations. 